\title{
The role of $K$ antigens as virulence factors in Klebsiella
}

\author{
A. M. SIMOONS-SMIT, A. M. J. J. VERWEIJ-VAN VUGHT and D. M. MACLAREN
}

\begin{abstract}
Research Group for Commercial Infections, Departments of Medical and Oral Microbiology, Schools of Medicine and Dentistry, Vrije Universiteit, 1007 MC Amsterdam, The Netherlands
\end{abstract}

\begin{abstract}
Summary. The importance of $\mathrm{K}$ antigen of Klebsiella as a virulence factor was studied in nine pairs of $\mathrm{K}^{+}$and $\mathrm{K}^{-}$strains, each pair isogenic apart from the presence of $\mathrm{K}$ antigen. Loss of $\mathrm{K}$ antigen by nine $\mathrm{K}^{+}$strains resulted in the reduced virulence of their $\mathrm{K}^{-}$variants in a mouse-skin model. This reduced virulence of $\mathrm{K}^{-}$strains for mice may be explained in all strains by a higher degree of phagocytosis as measured by chemiluminescence response of human polymorphonuclear leukocytes (PMNL) and in most strains by enhanced killing by either human PMNL or human serum or both. Although the protective role of the $\mathrm{K}$ antigen in serum-induced killing and killing by PMNL was generally evident, our results also suggested that other virulence factors were sometimes involved.
\end{abstract}

\section{Introduction}

Capsular antigens of Klebsiella have been implicated as important virulence factors in the pathogenesis of experimental klebsiella infections. In the past Toenniessen (1914) and Baerthlein (1918) demonstrated that capsule formation by Friedländer's bacillus was associated with virulence in laboratory animals and Edwards (1928) showed that extensive capsule production by Klebsiella was necessary to produce metritis in mares. More recently, the relationship between the size of capsule of Klebsiella pneumoniae sensu lato and pathogenicity in experimental lobar pneumonia, in an intraperitoneal model, or in a burn wound-sepsis model, have been shown with variants of strains of capsular serotypes 1 and 2 (Ehrenworth and Baer, 1956; Domenico et al., 1982; Cryz et al., 1984). Association between pathogenicity and capsule size has been studied in several other bacterial species, e.g., Escherichia coli (Glynn et al., 1971; McCabe et al., 1975; Verweij-van Vught et al., 1983), pneumococcus (MacLeod and Krauss, 1950) and Staphylococcus aureus (Melly et al., 1974). One mechanism whereby the increased virulence of encapsulated bacteria might be explained is the ability of the capsule or $\mathrm{K}$ antigen to prevent the killing of bacteria by serum and their phagocytosis by polymorphonuclear leukocytes (PMNL) as has been shown in particular for E. coli (Howard and Glynn, 1971; Rottini et al., 1975; Van Dijk et al., 1979; Verweij-van Vught et al., 1984). Although the

Received 10 May 1985; accepted 25 Jun. 1985. degree of encapsulation has been related to virulence in experimental klebsiella infections, the exact role of these $\mathrm{K}$ antigens in the pathogenesis of klebsiella infections has not been established.

In a previous study in which the virulence of clinical isolates of Klebsiella was examined in a mouse-skin model (Simoons-Smit et al., 1984), strains of capsular types $\mathrm{K} 1, \mathrm{~K} 2, \mathrm{~K} 4$ and $\mathrm{K} 5$ were of significantly greater virulence than strains of capsular type $\mathrm{K} 6$ and serotypes higher than 6 . In the present study, the role of the $K$ antigens in the virulence of Klebsiella was investigated by comparing capsulate $\left(\mathrm{K}^{+}\right)$and non-capsulate $\left(\mathrm{K}^{-}\right)$, but otherwise isogenic, pairs of strains in a mouse-skin model and by observing their susceptibility to killing by serum and their degree of phagocytosis by PMNL.

\section{Materials and methods}

\section{Bacterial strains}

Nine strains of $K$. pneumoniae of capsular types K 1 (6 strains), K2 (1) and K5 (2), previously shown to be virulent in our mouse model (Simoons-Smit et al., 1984), were used in this study. Strains were biotyped and serotyped by previously described methods (SimoonsSmit et al., 1984). Antibiotic sensitivity was tested by determination of minimum inhibitory concentrations in microtitration plates (MIC-2000 Dynatech).

\section{Detection of $\mathrm{K}^{-}$mutants}

$\mathrm{K}^{-}$mutant bacteria were detected as sectors of colonies 
with a slightly more translucent appearance on nutrient agar. After subculture of these sectors on nutrient agar, single colonies were subcultured on Worfel-Ferguson Agar before confirming the absence of $\mathrm{K}$ antigen in capsule-swelling tests made with undiluted homologous antiserum. Mutant bacteria were biotyped and their antibiotic-susceptibility patterns determined.

\section{Bacterial suspensions}

Nutrient-broth cultures of strains in the logarithmic phase of growth were harvested by centrifugation, resuspended in phosphate-buffered saline $(p \mathrm{H} \mathrm{7.4)}$ and stored overnight at $4^{\circ} \mathrm{C}$. Viable counts were determined by plating serial dilutions of the suspensions on nutrient agar. In all experiments, bacterial suspensions were diluted to $c .1 \times 10^{8} \mathrm{cfu} / \mathrm{ml}$.

\section{Virulence test}

Virulence for mice was tested as described previously (Simoons-Smit et al., 1984). Thus, $10^{7} \mathrm{cfu}$ were injected subcutaneously in the back of a mouse ( 2 injections per mouse) and the viable counts of skin lesions estimated after $24 \mathrm{~h}$ by the method of Maskell (1981). The growth index of 5-mm parallel cuts at 4-mm intervals in the lesions, after plating of these cuts in a standardised way, was graded as: 8 (confluent growth), 4 (semi-confluent growth), 2 ( $\geqslant 20$ colonies), 1 ( $<20$ colonies) and 0 (no growth). The total growth index was determined as the sum of the mean growth indices in the centre and $4 \mathrm{~mm}$ from the centre of the lesion. At least two mice (four lesions) were used per strain.

\section{Preparation of PMNL}

PMNL were separated from heparinised blood from healthy volunteers as described before (Simoons-Smit $e t$ al., 1985). The PMNL were resuspended in Hanks's Balanced Salts Solution (HBSS) to $5 \times 10^{6} \mathrm{PMNL} / \mathrm{ml}$ for chemiluminescence $(\mathrm{CL})$ experiments. For killing experiments, the $\mathrm{NH}_{4} \mathrm{Cl}$ treatment of PMNL for lysis of residual red cells was omitted and the PMNL were resuspended, after washing, to $1 \times 10^{7} \mathrm{PMNL} / \mathrm{ml}$.

\section{Chemiluminescence (CL)}

The induction of $\mathrm{CL}$ of PMNL was measured as described before (Simoons-Smit et al., 1985).

\section{Serum resistance}

The bactericidal effect of serum was estimated as follows: $0 \cdot 1 \mathrm{ml}$ of bacterial suspension $\left(1 \times 10^{8}\right.$ bacteria/ $\mathrm{ml}), 0.1 \mathrm{ml}$ of pooled normal human serum (NHS) and 0.8 $\mathrm{ml}$ of HBSS in polystyrene vials were incubated with shaking in a waterbath at $37^{\circ} \mathrm{C}$. Control tubes with heatinactivated $\left(56^{\circ} \mathrm{C}\right.$ for $\left.30 \mathrm{~min}\right)$ human serum (HIS) were included. Viable bacteria were estimated after incubation for 30,60 and $90 \mathrm{~min}$. The degree of serum resistance was graded as: $-=\geqslant 50 \% ; \quad+=11-50 \% ; \quad++=1-10 \%$; $+++=<1 \%$ survival of the inoculum.

\section{Killing by $P M N L$}

Killing experiments by human PMNL were performed as follows: $0.3 \mathrm{ml}$ of HBSS, $0.1 \mathrm{ml}$ of NHS, $0.5 \mathrm{ml}$ of PMNL $\left(1 \times 10^{7} \mathrm{PMNL} / \mathrm{ml}\right)$ and $0.1 \mathrm{ml}$ of bacterial suspension $\left(1 \times 10^{8}\right.$ bacteria/ml), giving a bacterium: leukocyte ratio of $2: 1$, were mixed in polystyrene vials and incubated with shaking in a waterbath at $37^{\circ} \mathrm{C}$. Samples $(0.1 \mathrm{ml})$ taken after 30,60 and 90 min were added to $9.9 \mathrm{ml}$ of distilled water at $0^{\circ} \mathrm{C}$ to lyse the PMNL without killing bacteria. Viable counts were determined by plating serial dilutions on nutrient agar.

\section{Results}

\section{Isolation of $\mathrm{K}^{-}$mutant strains of Klebsiella}

From the nine Klebsiella strains, $\mathrm{K}^{-}$mutant bacteria were isolated without mutagenic treatment. None of the $\mathrm{K}^{-}$isolates showed a positive capsule-swelling reaction with undiluted homologous antiserum whereas the capsulate parent strain gave positive capsule-swelling reactions with homologous antiserum at its working dilution. Differences in biotype or antibiotic-sensitivity pattern of parent and mutant strains were not observed.

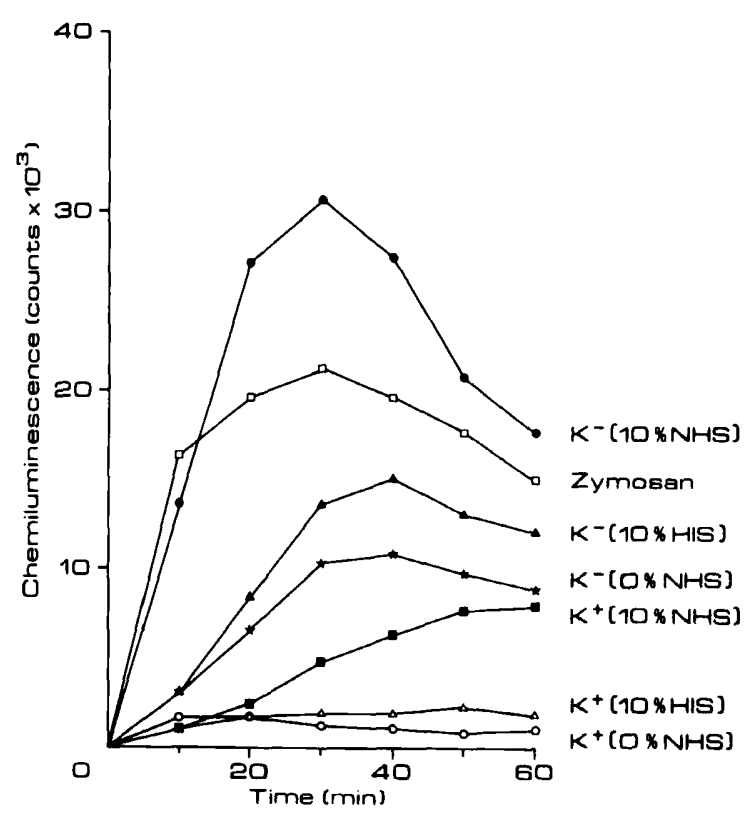

Fig. 1. Kinetics of chemiluminescence of PMNL activated by $\mathrm{K}^{+}$and $\mathrm{K}^{-}$variants of Klebsiella strain $\mathrm{KPl}$ in the presence of normal human serum $(10 \%$ NHS), or heat-inactivated human serum (HIS), or in the absence of normal human serum $(0 \%$ NHS). 


\section{Virulence for mice}

The virulence of the $\mathrm{K}^{+}$and $\mathrm{K}^{-}$strains was tested in a mouse model. Macroscopic examination revealed great differences in the lesions produced after $24 \mathrm{~h}^{\text {by }} \mathrm{K}^{+}$and $\mathrm{K}^{-}$strains. Thus, all $\mathrm{K}^{+}$ strains produced small abscesses with pus but without marked necrosis, whereas the $\mathrm{K}^{-}$strains produced mild induration only. The mean total growth indices of $\mathrm{K}^{-}$strains were much less than those of $\mathrm{K}^{+}$strains (table) and were similar to those previously reported for the avirulent strains of capsular types K6 and higher. During passage through mice, $\mathrm{K}^{-}$strains did not revert to the $\mathrm{K}^{+}$ phenotype.

\section{Chemiluminescence}

$\mathrm{CL}$ determinations measured the ability of $\mathrm{K}^{+}$ and $\mathrm{K}^{-}$strains to activate PMNL metabolism in the presence of serum. The results of one such experiment with the KP1 pair of strains are presented in fig. 1. Without NHS or with HIS, the CL response was always much lower than that of the same strain in the presence of $10 \%$ NHS indicating that complement was needed for optimal opsonisation of $\mathrm{K}^{+}$ and $\mathrm{K}^{-}$strains. The $\mathrm{CL}$ responses of the $\mathrm{K}^{+}$and $\mathrm{K}^{-}$strains, expressed as percentages of the $\mathrm{CL}$ responses induced by zymosan, are given in the table. The CL response of human PMNL was always higher for $\mathrm{K}^{-}$than $\mathrm{K}^{+}$strains.

\section{Serum resistance}

The $\mathrm{K}^{+}$and $\mathrm{K}^{-}$strains were tested for their sensitivity to killing in $10 \%$ NHS and the results of one such experiment are shown (fig. 2). The results for all $\mathrm{K}^{+}$and $\mathrm{K}^{-}$mutant strains are given in the table. These representative results showing changes in serum resistance after incubation for $60 \mathrm{~min}$ were also evident at 30 and $90 \mathrm{~min}$. Seven of the nine $\mathrm{K}^{+}$ strains were serum-resistant although a small initial killing was sometimes observed. With the loss of $\mathrm{K}$ antigen, five strains showed an enhanced killing in $10 \%$ NHS with a corresponding decrease in viable counts (to $<1 \%$ ) in the first 30 -min period. For the remaining four strains, however, differences in

Table I. Virulence, phagocytosis and killing of Klebsiella strains of different capsular serotypes and of their $\mathrm{K}$ antigen-negative mutant strains

\begin{tabular}{|c|c|c|c|c|c|}
\hline \multirow{2}{*}{$\begin{array}{c}\text { Strain } \\
\text { no. }\end{array}$} & \multirow{2}{*}{$\begin{array}{c}\text { Capsular } \\
\text { serotype } \\
\text { (K) }\end{array}$} & \multirow{2}{*}{$\begin{array}{c}\text { Virulence } \\
\text { (mean total } \\
\text { growth index) }\end{array}$} & \multirow[b]{2}{*}{ Chemiluminescence* } & \multicolumn{2}{|r|}{ Killing $\dagger$} \\
\hline & & & & $10 \%$ NHS & PMNL $+10 \%$ NHS \\
\hline $\begin{array}{l}\text { KP1.K+ } \\
\text { KP1.K }\end{array}$ & $\begin{array}{c}1 \\
\ldots\end{array}$ & $\begin{array}{r}23 \cdot 5 \\
5 \cdot 2\end{array}$ & $\begin{array}{r}29.5 \\
132.5\end{array}$ & $\overline{-}$ & $\begin{array}{c}+ \\
++\end{array}$ \\
\hline $\begin{array}{l}\text { KP2.K' } \\
\text { KP2. } K^{-}\end{array}$ & $\begin{array}{c}1 \\
\ldots\end{array}$ & $\begin{array}{r}14.0 \\
6.9\end{array}$ & $\begin{array}{r}51.5 \\
181.5\end{array}$ & $\begin{array}{l}- \\
-\end{array}$ & $\stackrel{+}{++}$ \\
\hline $\begin{array}{l}\text { KP3.K+ } \\
\text { KP3.K- }\end{array}$ & $\begin{array}{c}1 \\
\ldots\end{array}$ & $\begin{array}{r}17 \cdot 1 \\
5 \cdot 5\end{array}$ & $\begin{array}{r}83 \cdot 0 \\
179 \cdot 5\end{array}$ & $\overline{+}+$ & $\stackrel{+}{\mathrm{NM}}$ \\
\hline $\begin{array}{l}\text { KP4.K+ } \\
\text { KP4.K- }\end{array}$ & $\begin{array}{c}1 \\
\ldots\end{array}$ & $\begin{array}{r}20 \cdot 4 \\
4 \cdot 6\end{array}$ & $\begin{array}{r}28 \cdot 5 \\
143.5\end{array}$ & $\stackrel{+}{++}$ & $\stackrel{+}{\mathrm{NM}}$ \\
\hline $\begin{array}{l}\text { KP5.K+ }{ }^{+} \\
\text {KP5.K- }\end{array}$ & $\begin{array}{l}1 \\
\ldots\end{array}$ & $\begin{array}{r}24 \cdot 0 \\
5 \cdot 4\end{array}$ & $\begin{array}{r}38 \cdot 5 \\
122 \cdot 5\end{array}$ & $\begin{array}{c}+ \\
++\end{array}$ & $\stackrel{+}{\mathrm{NM}}$ \\
\hline $\begin{array}{l}\text { KP6.K+ } \\
\text { KP6.K- }\end{array}$ & $\begin{array}{c}1 \\
\ldots\end{array}$ & $\begin{array}{r}24 \cdot 0 \\
5 \cdot 2\end{array}$ & $\begin{array}{c}14.5 \\
123.0\end{array}$ & $\overline{+}+$ & $\overline{\mathrm{NM}}$ \\
\hline $\begin{array}{l}\text { KP7.K+ } \\
\text { KP7.K }\end{array}$ & $\begin{array}{c}2 \\
\ldots\end{array}$ & $\begin{array}{r}20 \cdot 5 \\
5 \cdot 2\end{array}$ & $\begin{array}{r}24 \cdot 5 \\
134 \cdot 5\end{array}$ & $\begin{array}{l}- \\
-\end{array}$ & $\overline{+}+$ \\
\hline $\begin{array}{l}\text { KP8.K+ } \\
\text { KP8.K- }\end{array}$ & $\begin{array}{c}5 \\
\ldots\end{array}$ & $\begin{array}{r}24 \cdot 0 \\
5 \cdot 4\end{array}$ & $\begin{array}{r}46 \cdot 0 \\
179 \cdot 5\end{array}$ & $\bar{t}+$ & $\overline{\mathrm{NM}}$ \\
\hline $\begin{array}{l}\text { KP9.K+ } \\
\text { KP9.K- }^{-}\end{array}$ & $\begin{array}{c}5 \\
\ldots\end{array}$ & $\begin{array}{r}22.0 \\
5.7\end{array}$ & $\begin{array}{r}74 \cdot 5 \\
190 \cdot 0\end{array}$ & $\begin{array}{l}- \\
-\end{array}$ & $\begin{array}{l}+++ \\
+++\end{array}$ \\
\hline
\end{tabular}

* Percentage of value with zymosan; values are the mean of at least two experiments.

$\dagger$ Survival of the inoculum after incubation for 60 min was: $-=>50 \% ;+=11-50 \%$; $++=1-10 \% ;+++=<1 \%$. Values are the mean of $2-6$ experiments. $N M=$ not measurable due to extreme sensitivity to killing by $10 \%$ NHS alone. 


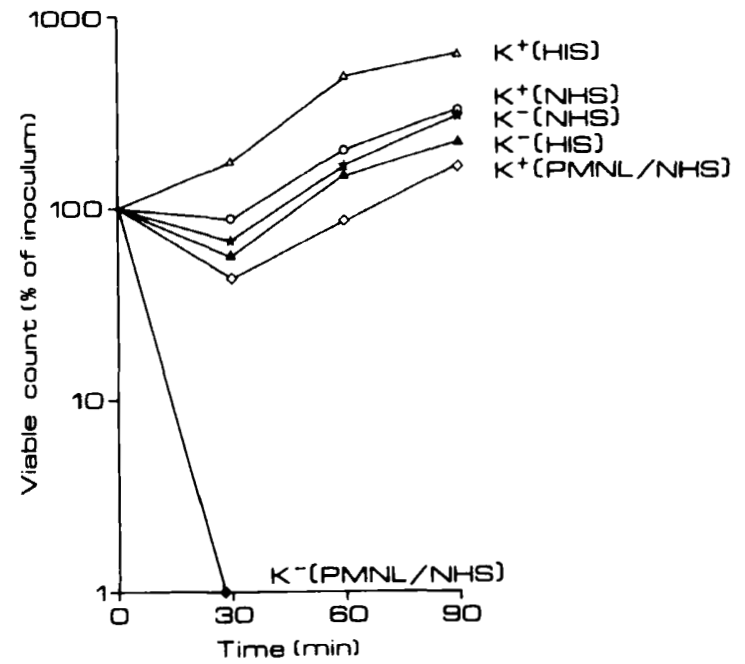

Fig. 2. Killing of $\mathrm{K}^{+}$and $\mathrm{K}$ variants of Klebsiella strain $\mathrm{KP} 2$ by PMNL in the presence of $10 \%$ normal human serum (PMNL/ NHS). Control experiments were made in the presence of $10 \%$ normal human serum (NHS) or heat-inactivated human serum (HIS) without PMNL.

serum killing between $\mathrm{K}^{+}$and $\mathrm{K}^{-}$strains were not observed. In control tests with $10 \%$ HIS, killing of $\mathrm{K}^{+}$or $\mathrm{K}^{-}$strains was not observed.

\section{Killing by PMNL}

Tests of killing by PMNL in the presence of $10 \%$ NHS were performed for all $\mathrm{K}^{+}$strains and the four serum-resistant $\mathrm{K}^{-}$strains and the results compared with those observed in $10 \%$ NHS alone. With the other five $\mathrm{K}^{-}$strains killing by PMNL was not measurable because of their extreme sensitivity to the lethal effects of $10 \%$ NHS alone. The viable counts of $\mathrm{K}^{+}$and $\mathrm{K}^{-}$variants of strain KP2 after incubation with PMNL and $10 \%$ NHS, with $10 \%$ NHS alone and with $10 \%$ HIS are shown (fig. 2). The results of killing by PMNL in the presence of $10 \%$ NHS after incubation for $60 \mathrm{~min}$ are shown in the table for all strains tested. Again, the results representative of the changes in killing after incubation for $60 \mathrm{~min}$ were also evident at 30 and $90 \mathrm{~min}$. There was little, or no, killing of $\mathrm{K}^{+}$strains other than strain KP9. An increase in the killing by PMNL was observed for three of the four serumresistant $\mathrm{K}^{-}$strains; both the $\mathrm{K}^{+}$and $\mathrm{K}^{-}$variants of strain KP9 were extremely sensitive to killing by PMNL.

\section{Discussion}

The importance of capsular polysaccharide of Klebsiella in relation to virulence has been well established (Ehrenworth and Baer, 1956; Hall and Humphries, 1958; Domenico et al., 1982; Mizuta et al., 1983; Williams et al., 1983; Cryz et al., 1984). Several hypotheses have been proposed for this involvement of $\mathrm{K}$ antigens in virulence, e.g., antiphagocytic activity and a barrier function against non-specific host-defence systems (Cryz et al., 1984).

This study was designed to investigate the influence on virulence of the $\mathrm{K}$ antigen of Klebsiella and to provide an explanation for the importance of these $\mathrm{K}$ antigens in infections. Strains isogenic apart from differences in $\mathrm{K}$ antigen were used; furthermore, $\mathrm{K}^{-}$strains were isolated without mutagenic treatment so that the occurrence of multiple mutations seemed unlikely.

With the loss of $\mathrm{K}$ antigen, the virulence of all $\mathrm{K}^{-}$ mutant strains was reduced in our mouse model suggesting that $\mathrm{K}$ antigen is an important factor in the establishment of infection by strains of Klebsiella of serotypes $\mathrm{K} 1, \mathrm{~K} 2$ and $\mathrm{K} 5$. Encapsulation may increase virulence by interference with phagocytosis and serum killing. All $\mathrm{K}^{-}$strains showed higher stimulation of CL in PMNL than the corresponding $\mathrm{K}^{+}$strains indicating better opsonisation of the $\mathrm{K}^{-}$strains. The higher $\mathrm{CL}$ obtained with the $\mathrm{K}^{-}$strains correlated well with the results of virulence when the strains were tested in our mouse model.

The interference of the $\mathrm{K}$ antigen with phagocytosis as measured with $\mathrm{CL}$ is confirmed by the results of our killing experiments with human PMNL. Encapsulated bacteria require specific anticapsular antibodies for effective opsonisation, as has been reported for $E$. coli (Welch and Stevens, 1979; Welch et al., 1979; Van Dijk et al., 1981) and Klebsiella (Williams et al., 1983). Because K antigens are generally less immunogenic than $\mathrm{O}$ antigens, the relative lack of anti-K antibodies in our pooled normal human serum (data not shown) may be responsible for the observed differences in opsonisation of $\mathrm{K}^{+}$and $\mathrm{K}^{-}$strains.

The results of serum-bactericidal tests performed with the $\mathrm{K}^{+}$strains and their $\mathrm{K}^{-}$derivates indicated that $\mathrm{K}$ antigens also determined resistance to serum killing in at least five strains. It is known that many factors may influence the complement-mediated bactericidal action of NHS. Besides K antigen, other components of the cell envelope, some of which have been shown to be plasmid-mediated (Reynard and Beck, 1976), are of great importance. Williams et al. (1983) emphasised the role of both O and $\mathrm{K}$ antigens in determining the resistance of $K$. aerogenes to serum killing and phagocytosis. From our experiments it is not clear how far $\mathrm{O}$ antigens 
and outer-membrane proteins contribute to the serum resistance of our serum-resistant $\mathrm{K}^{-}$mutant strains. For those $\mathbf{K}^{-}$derivate strains that remained serum-resistant, the $K$ antigen was presumably not a critical factor. Because we observed differences between $\mathrm{K}^{+}$and $\mathrm{K}^{-}$strains in opsonisation via complement, it seems likely that the late components of complement did not function in these serum-resistant $\mathrm{K}^{-}$strains.

From the observed differences between our isogenic $\mathrm{K}^{+}$and $\mathrm{K}^{-}$strains of Klebsiella in virulence, serum killing, phagocytosis (as measured by CL) and killing by human PMNL, we conclude that $\mathrm{K}$ antigen is an important virulence factor in Klebsiella strains. Nevertheless, other factors may affect the resistance of some strains to killing by serum and PMNL.

We thank Miss I. Engelen, Mrs O. Kempers and Mr W. Schouten for excellent technical assistance. This research was supported by grant no. 28-712 from the Praeventiefonds, 'sGravenhage.

\section{REFERENCES}

Baerthlein K 1918 Ueber bakterielle Variabilität insbesondere sogenannte Bakterienmutationen. Zentralblatt für Bakteriologie I.Abt. Orig. 81:369 435 .

Cryz S J, Fürer E, Germanier R 1984 Experimental Klebsiella pneumoniae burn wound sepsis: role of capsular polysaccharide. Infection and Immunity 43:440-441.

Domenico P, Johanson W G, Straus D C 1982 Lobar pneumonia in rats produced by clinical isolates of Klebsiella pneumoniae. Infection and Immunity 37:327-335.

Edwards P R 1928 The relation of encapsulated bacilli found in metritis in mares to encapsulated bacilli from human sources. Journal of Bacteriology 15:245-266.

Ehrenworth K, Baer H 1956 The pathogenicity of Klebsiella pneumoniae for mice: the relationship to the quantity and rate of production of type specific capsular polysaccharide. Journal of Bacteriology 72:713-717.

Glynn A A, Brumfitt W, Howard C J 1971 K antigens of Escherichia coli and renal involvement in urinary-tract infections. Lancet 1:514-516.

Hall H E, Humphries J C 1958 The relationship between insusceptibility to phagocytosis and virulence of certain Klebsiella pneumoniae strains. Journal of Infectious Diseases 103:157-162.

Howard C J, Glynn A A 1971 The virulence for mice of strains of Escherichia coli related to the effects of $\mathrm{K}$ antigens on their resistance to phagocytosis and killing by complement. Immunology 20:767-777.

McCabe W R, Carling P C, Bruins S, Greely A 1975 The relation of $\mathrm{K}$ antigen to virulence of Escherichia coli. Journal of Infectious Diseases 131:6-10.

MacLeod C M, Krauss M R 1950 Relation of virulence of pneumococcal strains for mice to the quantity of capsular polysaccharide formed in vitro. Journal of Experimental Medicine 92:1-9.

Maskell J P 1981 The pathogenicity of Bacteroides fragilis and related species estimated by intracutaneous infection in the guinea-pig. Journal of Medical Microbiology 14:131-140.

Melly M A, Duke L J, Liau D F. Hash J H 1974 Biological properties of the encapsulated Staphylococcus aureus M. Infection and Immunity 10:389-397.

Mizuta K, Ohta M, Mori M, Hasegawa T, Nakashima I, Kato N 1983 Virulence for mice of Klebsiella strains belonging to the Ol-group: relationship to their capsular $(\mathrm{K})$ types. Infection and Immunity 40:56-61.

Reynard A M, Beck M E 1976 Plasmid-mediated resistance to the bactericidal effects of normal rabbit serum. Infection and Immunity 14:848-850.

Rottini G, Dri P, Soranzo M R, Patriarca P 1975 Correlation between phagocytic activity and metabolic response of polymorphonuclear leukocytes toward different strains of Escherichia coli. Infection and Immunity 11:417-423.

Simoons-Smit A M, Verweij-van Vught A M J J, Kanis I Y R, MacLaren D M 1984 Virulence of Klebsiella strains in experimentally induced skin lesions in the mouse. Journal of Medical Microbiology 17:67-77.

Simoons-Smit A M, Verweij-van Vught A M J J, Kanis I Y R, MacLaren D M 1985 Chemiluminescence of human leukocytes stimulated by clinical isolates of Klebsiella. Journal of Medical Microbiology 19:333-338.

Toenniessen E 1914 Ueber Vererbung und Variabilität bei Bakterien mit besonderer Berücksichtigung der Virulenz. Zentralblatt für Bakteriologie I. Abt. Orig. 73:241-277.

Van Dijk W C, Verbrugh H A, Peters R, Van der Tol M E, Peterson P K, Verhoef J 1979 Escherichia coli K antigen in relation to serum-induced lysis and phagocytosis. Journal of Medical Microbiology 12:123-130.

Van Dijk W C, Verbrugh H A, Van Erne-van der Tol M E, Peters R, Verhoef J 1981 Escherichia coli antibodies in opsonisation and protection against infection. Journal of Medical Microbiology 14:381-389.

Verweij-van Vught A M J J, Van den Bosch J F, Namavar F, Sparrius M, MacLaren D M $1983 \mathrm{~K}$ antigens of Escherichia coli and virulence in urinary-tract infection:studies in a mouse model. Journal of Medical Microbiology 16:147-155.

Verweij-van Vught A M J J, Namavar F, Peerbooms P G H, Sparrius M, MacLaren D M 1984 The role of different K antigens of Escherichia coli in phagocytosis by polymorphonuclear leukocytes. Journal of Medical Microbiology 17:141-150.

Welch W D, Stevens P 1979 Serum requirements necessary for the opsonophagocytosis of Escherichia coli $073: \mathrm{K} 92: \mathrm{H}_{1}$. Current Microbiology 2:245-250.

Welch W D, Martin W J, Stevens P, Young L S 1979 Relative opsonic and protective activities of antibodies against $\mathrm{K}_{1}, \mathrm{O}$ and lipid A antigens of Escherichia coli. Scandinavian Journal of Infectious Disease 11:291-301.

Williams P, Lambert P A, Brown M R W, Jones R J 1983 The role of the $\mathrm{O}$ and $\mathrm{K}$ antigens in determining the resistance of Klebsiella aerogenes to serum killing and phagocytosis. Journal of General Microbiology 129:2181-2191. 